Tripathi and Prasad: Agricultural Development in India since Independence

0

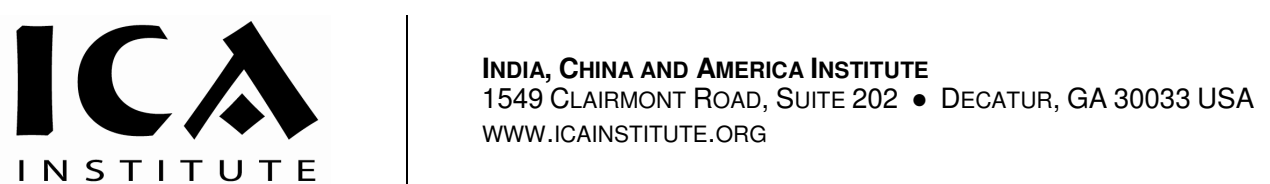

Agrienlitural Development in India since Independence: A Study on Progress, Performance, and Determinants

Published by DigitalCommons@Kennesaw State University, 2009 


\title{
Agricultural Development in India since Independence: A Study on Progress, Performance, and Determinants
}

\author{
Amarnath Tripathi \\ Agriculture Economic Research Unit \\ Institute of Economic Growth
}

\author{
A.R. Prasad \\ Department of Economics \\ Banaras Hindu University
}

Journal of Emerging Knowledge on Emerging Markets

Volume 1 Issue 1

November 2009

\section{Introduction}

griculture plays an essential role in the process of economic development of less developed countries like India. Besides providing food to nation, agriculture 1 releases labour, provides saving, contributes to market of industrial goods and earns foreign exchange. Agricultural development is an integral part of overall economic development. In India, agriculture was the main source of national income and occupation at the time of Independence. Agriculture and allied activities contributed nearly 50 percent to India's national income. Around 72 percent of total working population was engaged in 
agriculture. These confirm that Indian economy was a backward and agricultural based economy at the time of Independence. After 61 year of Independence, the share of agriculture in total national income declined from 50 percent in 1950 to 18 percent in 200708. But even today more than 60 percent of workforce is engaged in agriculture. In spite of this, it is also an important feature of agriculture that is to be noted that growth of other sectors and overall economy depends on the performance of agriculture to a considerable extent. Because of these reasons agriculture continues to be the dominant sector in Indian Economy.

Since independence India has made much progress in agriculture. Indian agriculture, which grew at the rate of about 1 percent per annum during the fifty years before Independence, has grown at the rate of about 2.6 percent per annum in the post-Independence era. Expansion of area was the main source of growth in the period of fifties and sixties after that the contribution of increased land area under agricultural production has declined over time and increase in productivity became the main source of growth in agricultural production. Another important facet of progress in agriculture is its success in eradicating of its dependence on imported foodgrains. Indian agriculture has progressed not only in output and yield terms but the structural changes have also contributed. All these developments in Indian agriculture are contributed by a series of steps initiated by Indian Government. Land reforms, inauguration of Agricultural Price Commission with objective to ensure remunerative prices to producers, new agricultural strategy ${ }^{1}$, investment in research and extension services, provision of credit facilities, and improving rural infrastructure are some of these steps.

Notwithstanding these progresses, the situation of agriculture turned adverse during postWTO period and this covered all the sub sectors of agriculture. The growth rates in output of all crops decelerated from 2.93 percent to 1.57 percent. The livestock declined from 4.21 percent to 3.40 percent. The fisheries declined from 7.48 percent to 3.25 percent. Only, forestry witnessed a sharp increase from 0.09 percent to 1.82 percent.

${ }^{1}$ In order to achieve the goal of self sufficiency in agriculture, new agricultural strategy has been initiated in 1966-67. The fundamental of this strategy is the application of science and technology for increasing yield per hectare. This strategy, known as New Agricultural Strategy or Green Revolution, is based on the extension of high yielding varieties responsive to heavy doses of fertilizers and the package of improved practices in selected areas with assured rainfall or irrigation facilities. The programmes included under the new strategy are: (1) the high yielding varieties programme, (2) multiple cropping programme, (3) integrated development of dry areas, (4) plant protection measures, (5) increased use of fertilizers, and (6) new irrigation concept. 
The crop sector, which forms largest segment of agriculture, showed poorest growth during post-WTO period in comparison to all other periods. Further, within crop sector, all crops except sugar showed declining trend between initial years of reforms and post-WTO period. This deceleration is very high in Cereals, Corse Cereals, Pulses, Oilseeds, and Drugs \& Narcotics. The growth rate turned negative in the case of pulses.

Both dominant nature of agriculture and decelerating growth trend in agriculture attracts attention of policymakers, researchers and economists. The main cause of failure of all development policy for agriculture is that there is no availability of any separate development strategy ${ }^{2}$ for Indian agriculture. This is due to the fact that we had not available necessary data to study the characteristics of Indian agriculture. But presently we have come a long way from Independence and now we have long-terms data pertaining to Indian agriculture. So, the present study makes attempt to fill this gap.

In this context, the present paper extensively evaluates performance and progress of Indian agriculture since Independence. Besides comparing facts and figures, we also examined sources of agricultural growth and instability of Indian agriculture for evaluating performance and progress of Indian agriculture. The paper also finds out determinates of agricultural production by using production function approach and verifies the results of decomposition of agricultural growth. This paper covered period from 1950-51 to 2005-06. We have chosen 1950-51 as starting period because all required data is not available (some data are available but sources are not authentic) for period before 1950-51 and 2006-07 as end period because the most recent data pertained to 2006-07 at the time of finalising the paper.

The rest of the paper is organized as follows. Section (ii) reviews previous agricultural policies. Section (iii) evaluates changes and performance of Indian agriculture since Independence. In this section, we discussed change in whole scenario of Indian agriculture over period of time. Section (iv) guesstimate sources of agricultural growth by decomposition analysis. Section (v) calculates instability in production, area, and yield of principal crops. Section (vi) estimates determinants of agricultural production by production function approach. Concluding remarks are presented in the final section.

\section{Agricultural Policy: A Review}

In this section, we try to trace out the principle government policies for promoting agricultural development. For the overall development of Indian agriculture, many institutional and infrastructural changes have been introduced since Independence. Broadly, agricultural policy followed during this period can be distinguished in four phases: first phase considered from 1947 to mid sixties, second phase considered period from mid-

${ }^{2}$ Agriculture production is a biological process, agriculture is diminishing returns activity because land is ultimately a fixed factor of production and the demand for agricultural commodities is income inelastic. These characteristics make different to agriculture from other sector. Therefore, a separate policy for agricultural development is must. 
sixties to 1980, third phase included period from 1980 to 1991 , and forth phase includes period from 1991/92 onwards.

The first phase of agricultural policy witnessed tremendous agrarian reforms, institutional changes, development of major irrigation project and strengthens of cooperative credit institution. The most important contribution of land reforms was abolition of intermediaries and giving land titles to the actual cultivators. This released productive forces and the owner cultivators put in their best to augment production on their holdings. Land reforms were important in increasing agricultural production during this phase. The Community Development Programme, decentralised planning and the Intensive Area Development Programmes were also initiated for regenerating Indian agriculture that had stagnated during the British period. In order to encourage the farmers to adopt better technology, incentive price policy was adopted in 1964 and the Agricultural Price Commission was set up to advice the Government on the fixation of support prices of agricultural crops. Despite the institutional changes and development programmes introduced by the Government during this phase, India remained dependent upon foreign countries for food to feed the rising population.

The second phase in Indian agriculture started in mid 1960s with adoption of new agricultural strategy ${ }^{3}$. The new agricultural strategy relies on high-yielding varieties of crops, multiple cropping, the package approach, modern farm practices and spread of irrigation facilities. The biggest achievement of this strategy has been attainment of self sufficiency in foodgrains. Agrarian reforms during this period took back seat while research, extension, input supply, credit, marketing, price support and spread of technology were the prime concern of policy makers (Rao, 1996).

The next phase in Indian agriculture began in early 1980s. This period started witnessing process of diversification which resulted into fast growth in non-foodgrains output like milk, fishery, poultry, vegetables, fruits etc which accelerated growth in agricultural GDP during the 1980s (Chand, 2003). There has been a considerable increase in subsidies and support to agriculture sector during this period while public sector spending in agriculture for infrastructure development started showing decline in real term but investment by farmers kept on moving on a rising trend (Mishra and Chand, 1995; Chand, 2001).

The fourth phase of agricultural policy started after initiation of economic reform process in 1991. Economic reforms process involved deregulation, reduced government participation in economic activities, and liberalization. Although there is no any direct reforms for agriculture but the sector was affected indirectly by devaluation of exchange rate, liberalization of external trade and disprotection to industry. During this period opening up of domestic market due to new international trade accord and WTO was another change that affected agriculture. This raised new challenges among policymakers. Because of this, a New Agricultural Policy was launched by Indian Government in July 2000. This aims to

${ }^{3}$ This is also known as Green Revolution strategy. 
attain output growth rate of 4 percent per annum in agriculture sector based on efficient use of resources. It seeks to achieve this objective in a sustainable manner and with equity. This was first time when government released a national agriculture policy. The policy document discusses what ought to be done in agriculture but the subsequent step, how and when policy goals and objective would be achieved is not discussed (Chand, 2003). Therefore, it is highly desirable to prepare action plans at both centre and state level in quantity terms to implement the new policy agenda in a time bound framework.

\section{Changing Agrarian Economy since Independence}

In this section we focused on how agrarian economy has changed since Independence. Keeping this view in mind this section follows land use pattern, population and agricultural workers, distribution of operational holding, and cropping pattern.

\section{Land Use Pattern}

The basic factor in agriculture is land. A knowledge about land use pattern is vital to understand whether the utilisation of land in India is at its full potential or far from its full potential. In India the classification of land has had its roots in agricultural statistics. Till 1950, the land in India was broadly classified into five categories: (i) Area under forests; (ii) Area not available for cultivation; (iii) Uncultivated lands including current fallows; (iv) Area under current fallows; and (v) Net area sown. But then it was realised that such a classification did not give a clear picture of the actual area under different categories of land use required for agricultural planning. Hence, a reclassification was adopted from March 1950. Under it, land in India now classified under nine different categories. These are as: (i) forests; (ii) barren and uncultivable lands; (iii) land put to non-agricultural uses; (iv) cultivable wastes; (v) permanent pastures and other grazing lands; (vi) miscellaneous tree crops and groves not included in the net area sown; (vii) current fallows; (viii) other fallows; and (ix) net sown area.

Table 1 shows changes in land use pattern in India since 1950/51.The total geographical area of the country is 328726 thousand hectares in which 93 percent area is reporting area which means that the area for which record is available. It was 88 percent in 1950/51. The net sown area has risen by 18.44 percent from $1950 / 51$ to $2000 / 01$. The net sown area is only 46 percent of total reporting area that was 41 percent of total reporting area in 1950/51. The area under non agricultural use has increased from 12690 thousand hectares to 24070 thousand hectares since 1950/51. But barren and uncultivable land has fallen from 37484 thousand hectares to 17709 thousand hectares. Both the cultivable waste land and fallow land have also decreased during this period. But even today 4.4 percent of total reporting area is available as a cultivable waste land and 4.8 percent of total reporting area is fallow land. This indicates that there is scope to increase the net sown area by at least 5 to 10 percent by improving both cultivable waste land and fallow. Gross sown area was 131893 thousand hectares in 1950/51 and it has increased to 185704 thousand hectares in 2001/02. 


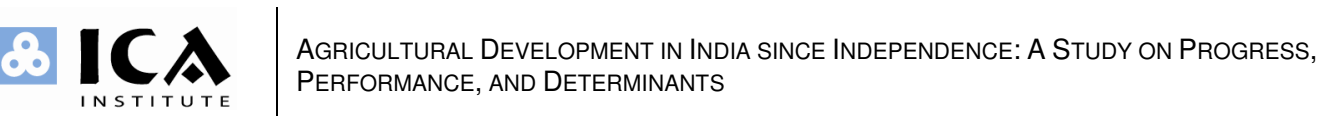

This shows that only 11 percent of net sown area was used for more than one crop in $1950 / 51$ and this figure increased to 31 percent in 2001/02. This point out that gross sown area can be increased by 70 percent of net sown area through intensive cropping.

\section{Table 1: Changes in Land Use Pattern in India from 1950-51 to 2001-02}

\begin{tabular}{lllllll} 
& \multicolumn{3}{c}{ (In Thousand Hectares) } \\
\hline Category & $1951-52$ & $1961-62$ & $1971-72$ & $1981-82$ & $1991-92$ & $2001-02$ \\
\hline Geographical Area & 328726 & 328726 & 328726 & 328726 & 328726 & 328726 \\
\hline Reporting Area for & 287827 & 299151 & 304141 & 304272 & 304900 & 305014 \\
land use & $(87.56)$ & $(91)$ & $(92.52)$ & $(92.56)$ & $(92.75)$ & $(92.79)$ \\
\hline Area under non & 12690 & 14795 & 16972 & 19686 & 21465 & 24070 \\
agricultural use & $(4.41)$ & $(4.95)$ & $(5.58)$ & $(6.47)$ & $(7.04)$ & $(7.89)$ \\
\hline Barren and & 37484 & 35921 & 27996 & 20010 & 19270 & 17709 \\
uncultivable land & $(13.02)$ & $(12.01)$ & $(9.20)$ & $(6.58)$ & $(6.32)$ & $(5.81)$ \\
\hline Net sown area & 119400 & 135399 & 139721 & 141928 & 141632 & 141416 \\
& $(41.48)$ & $(45.26)$ & $(45.94)$ & $(46.64)$ & $(46.45)$ & $(46.36)$ \\
\hline Gross sown area & 131893 & 152772 & 165791 & 172630 & 185742 & 185704 \\
\hline Cropping Intensity & 111 & 115 & 118 & 123 & 130 & 131 \\
\hline Forest land under & 48889 & 54189 & 63771 & 67422 & 67866 & 69511 \\
good tree cover & $(16.98)$ & $(18.11)$ & $(20.97)$ & $(22.15)$ & $(22.25)$ & $(22.79)$ \\
\hline Misc. tree crops & 7881 & 4500 & 4284 & 3715 & 3761 & 3370 \\
and groves & $(2.73)$ & $(1.50)$ & $(1.41)$ & $(1.22)$ & $(1.23)$ & $(1.10)$ \\
\hline Cultivable & 23929 & 18632 & 17456 & 16475 & 14994 & 13405 \\
wastelands & $(8.31)$ & $(6.23)$ & $(5.74)$ & $(5.41)$ & $(4.92)$ & $(4.39)$ \\
\hline Current fallows & 13808 & 11155 & 12669 & 13173 & 14672 & 14643 \\
& $(4.80)$ & $(3.73)$ & $(4.16)$ & $(4.33)$ & $(4.81)$ & $(4.80)$ \\
\hline Old fallows & 15154 & 10478 & 8312 & 9862 & 9941 & 10304 \\
& $(5.26)$ & $(3.50)$ & $(2.73)$ & $(3.24)$ & $(3.26)$ & $(3.38)$ \\
\hline Permanent & 8592 & 14082 & 12960 & 12007 & 11299 & 10586 \\
pastures and & $(2.98)$ & $(4.70)$ & $(4.26)$ & $(3.95)$ & $(3.71)$ & $(3.47)$
\end{tabular}

grazing lands

Note: figure in parentheses indicate percentage to Reported Area

Source: Agricultural Statistics at a Glance (2008)

\section{Changing Agricultural Structure}

We look at changing structure of Indian agriculture in terms of employment and land holding. The share of agriculture in employment declined from about 82 percent in 1950/51 to about 72 percent by 2001. During the same duration, the share of agriculture in total GDP also declined from 54.66 percent in 1950/51 to 24 percent by 2001.Among agricultural workforce about 45.6 percent are registered as agricultural labour and the rest, i.e., 54.4 percent as cultivators while 28.1 percent was registered as agriculture labour and the rest as 
cultivators in 1950/51. This indicates that agricultural workforce shifted from cultivators to agricultural labours (see Table 2).

Table 2: Population and Agricultural Workers in India since 1950-5

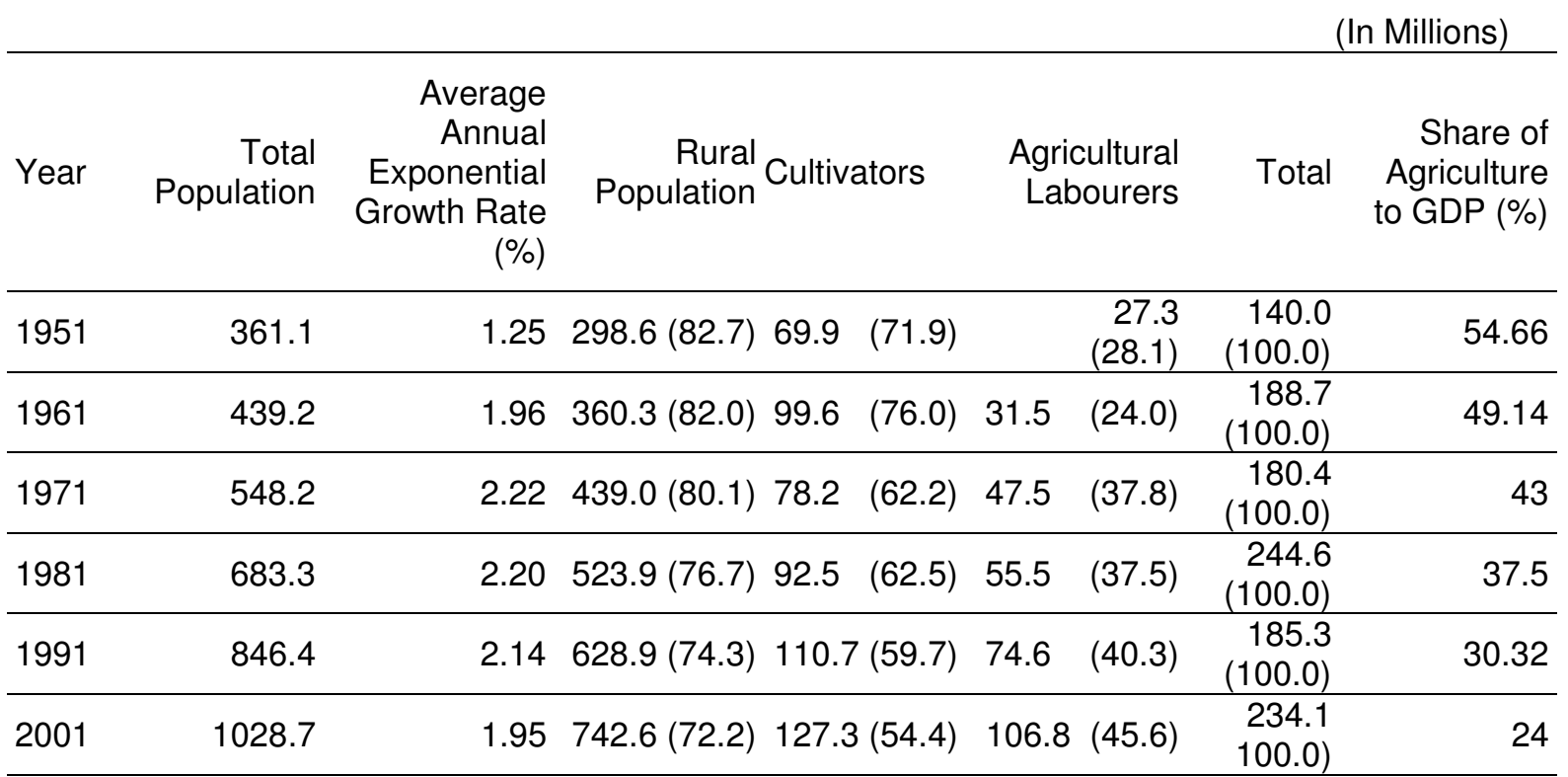

Note: figure in parentheses indicate percentage to Reported Area

Source: Agricultural Statistics at a Glance (2008)

There were 48900 million operational holding in 1960/61 and covered area of 131400 million hectares. These operational holding increased to 115580 million in 2000/01and covered area of 163357 million hectares. It shows that the number of operational holding has increased by about 66680 million units but the area covered by then has not significantly increased. It implies that size of operational holding has been reducing.

Table 3 shows that the number of marginal and small holdings and the area under such holdings has increased while the number of semi-medium, medium, and large holdings and the area under such holdings has reduced. It reveals that the inequalities in the distribution of land among the cultivators has reducing trend but the number of uneconomic holdings has an increasing trend, i.e., small and marginal holdings are increasing in both number and percentage. 
Table 3: The Percentage Distribution of Operational Holding by Size Class, 1960-61 to 2000-01

\begin{tabular}{|c|c|c|c|c|c|}
\hline \multicolumn{6}{|c|}{ (i) Share in Number of Holding (In Percentage) } \\
\hline Category of holdings & $1960-61$ & $1970-71$ & $1980-81$ & $1990-91$ & $2000-01$ \\
\hline Marginal & 40.69 & 50.6 & 56.4 & 59.4 & 63.0 \\
\hline Small & 22.29 & 19.1 & 18.1 & 18.8 & 18.80 \\
\hline Semi-Medium & 18.8 & 15.2 & 14.0 & 13.1 & 11.7 \\
\hline Medium & 13.4 & 11.3 & 9.1 & 7.1 & 5.4 \\
\hline Large & 4.9 & 3.9 & 2.4 & 1.6 & 1.02 \\
\hline \multicolumn{6}{|c|}{ (ii) Share in Operated Area (In Percentage) } \\
\hline Marginal & 6.6 & 9.0 & 12.0 & 15.1 & 18.82 \\
\hline Small & 12.17 & 11.9 & 14.1 & 17.4 & 20.18 \\
\hline Semi-Medium & 19.93 & 18.4 & 21.2 & 23.2 & 23.96 \\
\hline Medium & 30.51 & 29.8 & 19.6 & 27.0 & 23.84 \\
\hline Large & 30.74 & 30.9 & 23.0 & 17.3 & 13.21 \\
\hline \multicolumn{6}{|c|}{ (iii) Average Size (In Hectares) } \\
\hline Marginal & & 0.41 & 0.39 & 0.39 & 0.40 \\
\hline Small & & 1.44 & 1.44 & 1.43 & 1.41 \\
\hline Semi-Medium & & 2.81 & 2.78 & 2.76 & 2.72 \\
\hline Medium & & 6.08 & 6.02 & 5.9 & 5.80 \\
\hline Large & & 18.1 & 17.41 & 17.33 & 17.18 \\
\hline
\end{tabular}

Note: 1 . Marginal -0 to 1 hectare; Small -1 to 2 hectare; Semi-medium -2 to 4 hectare; Medium - 4 to 10 hectare; and Large -10 and above hectare. Source: Agricultural Census Division, Ministry of Agriculture, New Delhi.

\section{Changes in Cropping Pattern}

Cropping pattern means the proportion of area under different crops at a particular period of time. A change in cropping pattern means a change in the proportion under different crops. Table 4 indicates that the area under non-food crops as a proportion of the total cropped area is increasing but still there is dominance of food crops. At the beginning of the economic planning in India, 76.7 percent land was put under food crops and about 23.3 percent on non-food crops. By 2001, area under food crops had come down to 65.83 percent and under non-food crops has increased to 34.17 percent. This shift in the allocation of area from food crops to non-food crops reflect a change from subsistence cropping to commercial cropping. This shifting of land from food crops to non-food crops was mainly influenced by the prevailing price in market and profitability per hectare.

Similarly, here it can also be concluded that, there is preponderance of cereals, about 54.43 percent of the area is devoted to the production of cereals, while only 11.4 percent is devoted to pulses. Though, the area under both cereals and pulses is increasing but the rate of increase in area under cereals is greater than that of pulses. It means whatever cropped area increased as a result of irrigation facilities, chemical fertiliser, and high yielding varieties of seeds, a greater part of it is devoted to foodgrains. Within cereals, area under 
coarse cereals is gradually declining since $1950 / 51$. This is due to fact that coarse cereals are inferior goods.

Table 4: Changes in Cropping Pattern in India since 1950-51

\begin{tabular}{lrrrrrr} 
& & & \multicolumn{3}{c}{ (In Percent) } \\
\hline Crops & $1950-51$ & $1960-61$ & $1970-71$ & $1980-81$ & $1990-91$ & $2000-01$ \\
\hline Rice & 23.5 & 22.3 & 22.6 & 23.3 & 23 & 24.03 \\
\hline Wheat & 7.6 & 8.5 & 11 & 12.8 & 12.9 & 13.84 \\
\hline Corse Cereals & 29.9 & 29.4 & 27.8 & 24.6 & 19.6 & 16.55 \\
\hline Total Cereals & 61.1 & 60.2 & 61.4 & 60.8 & 55.5 & 54.43 \\
\hline Total Pulses & 15.6 & 15.5 & 14 & 13.2 & 13.5 & 11.4 \\
\hline Total Foodgrains & 76.7 & 75.7 & 75.4 & 73.9 & 68.9 & 65.83 \\
\hline Sugarcane & 1.3 & 1.6 & 1.6 & 1.7 & 2.1 & 2.49 \\
\hline Condiments \& & 0.9 & 1 & 1.1 & 1.2 & 1.3 & 1.5 \\
Spices & & & & & & \\
\hline Fruits \& Vegetable & 1.7 & 1.9 & 2 & 1.7 & 3.6 & 4.39 \\
\hline Total Oilseeds & 8.3 & 8.3 & 8.9 & 9.1 & 13.5 & 13.56 \\
\hline Total Fibres & 5.1 & 5.7 & 5.5 & 5.3 & 4.7 & 5.22 \\
\hline Tobacco & 0.3 & 0.3 & 0.2 & 0.3 & 0.2 & 0.16 \\
\hline Source: Agricultura
\end{tabular}

Source: Agricultural Statistics at a Glance (2008)

Furthermore, Table 4 also shows that area under fruits and vegetables and oilseeds is gradually increasing since $1950 / 51$. This is because the consumption pattern is shifting from cereals to non-cereals. This phenomenon can be seen in Tables 5 and 6.

\section{Table 5: Trends in Food Consumption Pattern from 1972-73 to 2004-05, All India (Rural)}

\begin{tabular}{|c|c|c|c|c|c|c|c|c|c|c|c|}
\hline \multirow[b]{2}{*}{ Sector } & \multirow[b]{2}{*}{ Year } & \multicolumn{10}{|c|}{$\%$ share of major food groups in total expenditure } \\
\hline & & $\begin{array}{l}\text { All } \\
\text { food }\end{array}$ & Cereals & Pulses & $\begin{array}{l}\text { Milk \& } \\
\text { milk } \\
\text { products }\end{array}$ & $\begin{array}{l}\text { Edible } \\
\text { oil }\end{array}$ & $\begin{array}{l}\text { Egg, Fish } \\
\& \text { meat }\end{array}$ & $\begin{array}{l}\text { Vegeta } \\
\text { bles }\end{array}$ & $\begin{array}{l}\text { Fruits \& } \\
\text { nuts }\end{array}$ & Sugar & $\begin{array}{l}\text { Beverages } \\
\& \text { etc }\end{array}$ \\
\hline \multirow[t]{5}{*}{ Rural } & $72-73$ & 72.9 & 40.6 & 4.3 & 7.3 & 3.5 & 2.5 & 3.6 & 1.1 & 3.8 & 2.4 \\
\hline & $87-88$ & 64.0 & 26.3 & 4.0 & 8.6 & 5.0 & 3.3 & 5.2 & 1.6 & 2.9 & 3.9 \\
\hline & 93-94 & 63.2 & 24.2 & 3.8 & 9.5 & 4.4 & 3.3 & 6.0 & 1.7 & 3.1 & 4.2 \\
\hline & $99-00$ & 59.4 & 22.2 & 3.8 & 8.8 & 3.7 & 3.3 & 6.2 & 1.7 & 2.4 & 4.2 \\
\hline & 04-05 & 55.0 & 18.0 & 3.1 & 8.5 & 4.6 & 3.3 & 6.1 & 1.9 & 2.4 & 4.5 \\
\hline
\end{tabular}

Source: $61^{\text {st }}$ Round Report of NSS, Ministry of Statistics and Programme implementation, New

Delhi. 


\section{Table 6: Trends in Food Consumption Pattern from 1972-73 to 2004-05, All India (Urban)}

\begin{tabular}{|c|c|c|c|c|c|c|c|c|c|c|c|}
\hline \multicolumn{12}{|c|}{$\%$ share of major food groups in total expenditure } \\
\hline Sector & Year & $\begin{array}{l}\text { All } \\
\text { food }\end{array}$ & Cereals & Pulses & $\begin{array}{l}\text { Milk \& } \\
\text { milk } \\
\text { products }\end{array}$ & $\begin{array}{l}\text { Edible } \\
\text { oil }\end{array}$ & $\begin{array}{l}\text { Egg, Fish } \\
\& \text { meat }\end{array}$ & $\begin{array}{l}\text { Vegeta } \\
\text { bles }\end{array}$ & $\begin{array}{l}\text { Fruits \& } \\
\text { nuts }\end{array}$ & Sugar & $\begin{array}{l}\text { Beverages } \\
\& \text { etc }\end{array}$ \\
\hline \multirow[t]{5}{*}{ Urban } & $72-73$ & 64.5 & 23.3 & 3.4 & 9.3 & 4.9 & 3.3 & 4.4 & 2.0 & 3.6 & 7.6 \\
\hline & $87-88$ & 56.4 & 15.0 & 3.4 & 9.5 & 5.3 & 3.6 & 5.3 & 2.5 & 2.4 & 6.8 \\
\hline & $93-94$ & 54.7 & 14.0 & 3.0 & 9.8 & 4.4 & 3.4 & 5.5 & 2.7 & 2.4 & 7.2 \\
\hline & $99-00$ & 48.1 & 12.4 & 2.8 & 8.7 & 3.1 & 3.1 & 5.1 & 2.4 & 1.6 & 6.4 \\
\hline & $04-05$ & 42.5 & 10.1 & 2.1 & 7.9 & 3.5 & 2.7 & 4.5 & 2.2 & 1.5 & 6.2 \\
\hline
\end{tabular}

Source: $61^{\text {st }}$ Round Report of NSS, Ministry of Statistics and Programme implementation, New Delhi.

Following inferences can be drawn in these two tables.

1. The share of food in the total budget expenditure of a household has been showing a decline over the years in both rural and urban sector. In rural all India, the share of food declined from 72.9 percent in 1972-73 to 55 percent in 2004-05 and in urban all India it declined from 64.5 percent in 1972-73 to 42.5 percent in 2004-05.

2. Although cereal continues to be the important constituent of a household's food bosket, its share in total budget is declining.

3. The share of pulses is also showing declining trend.

4. The consumption of vegetables and fruits, milk, meat, egg, and fish, and edible oil has shown an increase.

The structural shift in consumption pattern is on account of the consumption diversification effect because of easy access to supply, changed tastes and preferences, and change in relative prices (Radhakrishna and Ravi 1992; Kumar 1998; Murthy 2000). Increasing urbanization and economic growth reduces per capita demand for cereals and increases the demand for non-cereals food items. Modernisation of agricultural also bears a similar negative relationship with the per capita consumption of cereals. Mechanization of agricultural activities and improvement in infrastructure also contribute to reduction in energy requirement and thus less cereal consumption (Rao 2000).

\section{Performance of Indian Agriculture}

\section{Output Growth}

Agricultural growth is one of the main facets of India's economic development and national food sufficiency policies. Tables 7-8 show the growth rate of agriculture by sector and 
different crop wise. The aggregate agricultural output increased annually at 2.6 percent during period from 1950/51-2006/07. Disaggregating of aggregate agricultural output growth into sub periods shows that annual growth rate of agriculture was the highest during the period 1981/82-1990/91 and the lowest during period 1950/51-1965/66. Further disaggregating of agriculture into sub sectors; crop, livestock, forestry, and fishing, shows that fisheries and livestock were the main sources of the acceleration in growth rate of agricultural output in 1980s. The growth rate of aggregate agricultural output turned up 3.29 percent during the initial years of reforms, which was 0.43 percentage point higher than the previous period. However, the situation of agriculture turned adverse during postWTO period and this covered all the sub sectors of agriculture. The growth rates in output of all crops decelerated from 2.93 percent to 1.57 percent. The livestock declined from 4.21 percent to 3.40 percent. The fisheries declined from 7.48 percent to 3.25 percent. Only, forestry witnessed a sharp increase from 0.09 percent to 1.82 percent.

\section{Table 7: Average Annual Compound Growth in Value of Output (Group Wise)}

\begin{tabular}{llllll}
\hline Group & $1950 / 51-$ & $1966 / 67-$ & $1981 / 82-$ & $1991 / 92-$ & (In Percent) \\
& $1965 / 66$ & $1980 / 81$ & $1990-91$ & $2006 / 07$ & $2006 / 07$ \\
\hline Crop & 2.4 & 2.6 & 2.4 & 2.2 & 2.5 \\
\hline Livestock & 1.3 & 3.2 & 4.4 & 3.4 & 3.1 \\
\hline Forestry & 1.3 & 00 & 00 & 1.5 & 0.6 \\
\hline Fishing & 4.5 & 3.1 & 5.8 & 4.0 & 4.2 \\
\hline Aggregate & 2.1 & 2.5 & 2.8 & 2.6 & 2.6 \\
\hline
\end{tabular}

Note: Annual compound growth rates have been calculated by using log linear model

\section{Table 8: Average Annual Compound Growth in Value of Output (Crop Wise)}

\begin{tabular}{llllll} 
& \multicolumn{1}{l}{} & & (In Percent) \\
\hline Crop & $1950 / 51-$ & $1966 / 67-$ & $1981 / 82-$ & $1991 / 92-$ & $1950 / 51$ - \\
& $1965 / 66$ & $1980 / 81$ & $1990-91$ & $2006 / 07$ & $2006 / 07$ \\
\hline Rice & 3.6 & 2.6 & 4.0 & 0.9 & 2.5 \\
\hline Wheat & 3.4 & 6.4 & 3.2 & 1.4 & 4.7 \\
\hline Coarse Cereals & 1.6 & 0.9 & 0.7 & 0.5 & 0.9 \\
\hline Pulses & 1.1 & 0.5 & 1.6 & 0.4 & 0.6 \\
\hline Oil seeds & 2.5 & 1.4 & 5.4 & 0.7 & 2.6 \\
\hline Sugar & 4.4 & 2.5 & 2.6 & 4.1 & 2.9 \\
\hline Fibres & 3.1 & 2.1 & 2.6 & 1.6 & 2.2 \\
\hline Drugs \& Narcotise & 2.1 & 3.2 & 2.2 & 2.6 & 2.7 \\
\hline Condiments \& & 2.5 & 3.2 & 4.5 & 4.9 & 3.3 \\
Spices & & & & & \\
\hline Fruits \& Vegetables & 1.8 & 4.3 & 2.1 & 4.3 & 3.8 \\
\hline Others & 00 & 0.4 & 00 & 4.6 & 0.6 \\
\hline
\end{tabular}

Note: Annual compound growth rates have been calculated by using log linear model 
The crop sector, which forms the largest segment of agriculture, grew annually at 2.5 percent since 1950/51. The acceleration rate of crop sectors fluctuated around 2.5 percent during all sub periods. It grew at the lowest rate during post-WTO period in comparison to all other periods. Further, within crop sector, all crops except sugar, condiment, spices, fruits and vegetables showed declining trend between 1950/51-1965/66 and 1991/922006/07. This deceleration is very high in Cereals, Corse Cereals, Pulses, Oilseeds, and Drugs \& Narcotics. Similar declining trend in growth rate of all crops is also confirmed by Table 9 that shows average annual compound growth rate of output in physical term for all major crops.

Table 9: Average Annual Compound Growth in real term (Crop Wise)

\begin{tabular}{lllllll}
\multicolumn{1}{c}{} & \multicolumn{3}{c}{ (In Percent) } \\
\hline Crop & $1950 / 51-$ & $1950 / 51-$ & $1966 / 67-$ & $1981 / 82-$ & $1991 / 92-$ & $1950 / 51-$ \\
& $2006 / 07$ & $1965 / 66$ & $1980 / 81$ & $1990-91$ & $2006 / 07$ & $2006 / 07$ \\
\hline Rice & 2.5 & 3.6 & 2.6 & 4.1 & 1.0 & 2.5 \\
\hline Wheat & 4.7 & 3.7 & 6.3 & 3.3 & 1.4 & 4.7 \\
\hline Coarse Cereals & 0.9 & 2.2 & 0.9 & 0.7 & 0.7 & 0.9 \\
\hline Pulses & 0.5 & 1.6 & 0.2 & 1.4 & 0.2 & 0.5 \\
\hline Oil seeds & 2.9 & 2.8 & 2.1 & 5.6 & 0.9 & 2.9 \\
\hline Cotton & 2.4 & 3.6 & 2.5 & 3.2 & 2.7 & 2.4 \\
\hline Jute \& Mesta & 1.5 & 4.4 & 2.1 & 0.7 & 1.5 & 1.5 \\
\hline Sugarcane & 3.1 & 6.2 & 3.0 & 2.9 & 0.8 & 3.1 \\
\hline Tobacco & 1.5 & 2.4 & 2.1 & 0.0 & -0.1 & 1.5 \\
\hline Potato & 5.4 & 5.4 & 7.2 & 4.9 & 3.1 & 5.4 \\
\hline
\end{tabular}

Note: Annual compound growth rates have calculated by using log linear model

These growth rates are lower than the growth rate of rural population. Thus, the clear implication of this growth trends is that the per capita output in agriculture is declining. This seems to be one of the causes for rising disparity between rural and urban areas in India.

\section{Net Availability of Foodgrains}

Table 10 shows net availability of foodgrains for per capita per day. An average availability of foodgrains per capita per day was 429.8 gram in 1950 s and increased to 475.5 gram during 1990s. Further, it decreased to 446.6 gram in the first decade of $21^{\text {st }}$ century. Within foodgrains, all food crops reveals similar trend except coarse cereals. The availability of coarse cereals is continuously declining. 
Table 10: Net availability of foodgrains (per day) India

\begin{tabular}{lrrrrrrr}
\hline Decades & Rice & Wheat & $\begin{array}{c}\text { Other } \\
\text { Cereals }\end{array}$ & Cereals & Gram & Pulses & Foodgrains \\
& & & & & & & \\
\hline $1951-60$ & 178.1 & 65.9 & 119.4 & 363.4 & 27.5 & 66.4 & 429.8 \\
\hline $1961-70$ & 188.3 & 91.1 & 113.5 & 392.9 & 22.6 & 54.7 & 447.5 \\
\hline $1971-80$ & 183.0 & 114.8 & 100.9 & 398.7 & 17.0 & 43.5 & 442.2 \\
\hline $1981-90$ & 198.1 & 143.3 & 83.2 & 424.6 & 13.2 & 39.6 & 464.2 \\
\hline $1991-2000$ & 209.3 & 162.7 & 67.7 & 439.7 & 12.3 & 35.8 & 475.5 \\
\hline $2001-2005$ & 194.7 & 159.9 & 59.0 & 414.2 & 9.8 & 32.4 & 446.6
\end{tabular}

Source: Agricultural Statistics at a Glance (2008)

\section{Input Use Pattern}

Agricultural production and efficiency largely depend upon the inputs applied and the methods adopted. In India, "while population grows, the land surface is fixed and of this only a certain proportion is available for cultivation" (Planning commission, 1961). Further scope for bringing extra land under the plough is limited. If more production is to be got out of this existing area, the problem has to be tackled on a wide front. This can be done by applying inputs in a more intensive way and by adopting modern methods of production through use of improved technology, besides making an adequate provision for institutional financing, better methods of marketing, etc.

Technical factors, i.e., technology have received increasing emphasis and the recent breakthrough in agriculture is the outcome of these factors. These technological factors comprise (i) irrigation; (ii) Consumption of fertilisers and manure; (iii) Improved seed, and (iv) agricultural implements.

Water is another basic factor in agriculture next only to land. Only rainfall is the natural source of water in agriculture. But rainfall is the most unreliable and is marked by wide variations in different parts and also variation from year to year in its quantity, incidence, and duration. Therefore, only artificial supply of water through irrigation is the way to overcome the problem of deficiency of water. Irrigation water comes from two sources: surface water and ground water. Surface water is provided by the flowing water of rivers or the still water of tanks, ponds, lakes, and artificial reservoirs. The surface water is carried to the filed by canals, distributaries, and channels. Ground water is tapped by sinking wells where drought animals, diesel or electric power is utilized to take out water. In india canals, tanks, wells including tubewells are the principal sources of irrigation. Since 1950-51, considerable importance had been attached to the provision of canal irrigation and well irrigation. Even though 40 percent of irrigation is supplied by canals, now well irrigation has caught up rapidly irrigation by tubwells has been expanded considerably. In the meantime, tanks and other source of irrigation are declining in importance (see Table 11). 
Table 11: Sources of Irrigation

\begin{tabular}{lcccccc}
\hline Sources & $1950 / 51$ & \multicolumn{1}{c}{$1970-71$} & \multicolumn{2}{c}{$2000 / 01$} \\
\hline & $\begin{array}{c}\text { Area (Million } \\
\text { ha) }\end{array}$ & $\%$ & $\begin{array}{c}\text { Area (Million } \\
\text { ha) }\end{array}$ & $\%$ & $\begin{array}{c}\text { Area (Million } \\
\text { ha) }\end{array}$ & $\%$ \\
\hline Canals & 8.29 & 44.0 & 12.80 & 40.5 & 17.1 & 31.3 \\
\hline $\begin{array}{l}\text { Wells } \\
\text { including } \\
\text { tubewells }\end{array}$ & 5.98 & 31.7 & 12.10 & 38.3 & 30.9 & 56.6 \\
\hline Tanks & 3.61 & 19.1 & 4.10 & 13.0 & 3.1 & 5.7 \\
\hline Others & 0.97 & 5.2 & 2.60 & 8.2 & 3.5 & 6.4 \\
\hline Total & 18.85 & 100 & 31.60 & 100 & 54.6 & 100 \\
\hline
\end{tabular}

Source: Indian Agriculture in brief, $21^{\text {st }}$ Edn, 1986 CMIE, Statistical Abstract, India, 2004

Table 12 shows that the net irrigated area has risen by 163 percent from 1950/51 to 2000/01. This increment in irrigated area is very nominal and only 39 percent of net sown area is irrigated area. This figure is very unsatisfactory and it is matter of concern that why only 39 percent of net sown area is irrigated area. It is also concerning matter that growth in gross irrigated area is also very nominal. Thus, there is scope to increase agricultural production by increasing both net and gross irrigated area.

Table 12: Changes in Irrigated Area in India from 1950-51 to 2000-01

\begin{tabular}{lllllll} 
& & \multicolumn{4}{c}{ (In Thousand Hectares) } \\
\hline Category & $1950-51$ & $1960-61$ & $1970-71$ & $1980-81$ & $1990-91$ & $2000-01$ \\
\hline Net irrigated area & 20853 & 24661 & 31103 & 38720 & 48023 & 54836 \\
\hline Gross irrigated area & 22563 & 27980 & 38195 & 49775 & 63204 & 75821 \\
\hline $\begin{array}{l}\text { Irrigation intensity } \\
\text { (In percent) }\end{array}$ & 108 & 113 & 123 & 128 & 132 & 138 \\
\hline $\begin{array}{l}\text { Note: Irrigation intensity is calculated by author. } \\
\text { Source: Agricultural Statistics at a Glance (2008 }\end{array}$ & & & & & \\
\end{tabular}

In any scheme for boosting agricultural output, the use of chemical fertiliser has an important role. India's soil though varied and rich in deficient in nitrogen and phosphorustwo plants nutrients which together with organic manure influence crop return, which population rising at a first rate, the use of larger and larger doses of chemical fertiliser is the only way to augment our foodgrains production. The new agricultural strategy was based on increased use of fertiliser.

Since adoption of the new agricultural strategy in the sixties, the consumption of chemical fertiliser has been growing rapidly. The Government is also encouraging the use of fertiliser through heavy subsidies. That is why the consumption has gone up abnormally high from 70000 tonnes in $1950-51$ to $2,177,000$ tonnes in 1970-71, 12,546,000 tonnes in 1990-91 and 
19,145,000 tonnes in 1999-2000 (see Table 13). The fertiliser consumption per hectare of gross cropped area has also gone up steadily, from $0.50 \mathrm{~kg}$ in $1950-51$ to $74 \mathrm{~kg}$ in $1995-96$. The corresponding figures for developed countries are much higher than the Indian Agriculture (see Table 14).

The low consumption may be due to the poor economic condition of farmers, lack of assured irrigation (58.5\% of the cropped area lack irrigation facilities), inadequate demonstration and promotion for the use of fertilisers, insufficient supply at the proper time, high price of fertiliser, absence of soil testing facilities so as to recommended the precise deficiencies in the soil and recommended proper dose of fertiliser, and wrong notion among some conservative farmers regarding the use of chemical fertilisers.

Improved seeds have played vital role in augmenting agricultural production in developing countries like India. These seeds not only help in increasing in agricultural production by 10 to 20 percent but introducing new characteristics in the biological structure of the plant. For, example researches have made it possible to develop such seeds which are quick maturing, provide higher agricultural yield and are resistant to insects, diseases and droughts. In India the success of Green Revolution is partly associated with the use of high yield variety (HYV) seeds. The HYV programme was started in 1966. Between 1967-68 and 1996-97 the area under HYVP has witnessed 12.6 times increase (from 6.07 million ha to 76 million ha). The success of the programme remains most marked in the case of wheat and rice. The HYV programme has led to 4.84 times increase in the output of wheat from 1966-67 (11.39 million tonnes) to 1990-91 (51.1 million tonnes) and 1.78 times increase in the production of rice from 1967-68 (37.6 million tonnes) to 1990-91 (74.3 million tonnes).

The implements and tools used by the Indian farmers are primitive, crude, and obsolete which impede the development of modern agriculture. New farm machineries not only save time, reduce cost of production but also increase agricultural production. These machineries replace the animal and human power and perform various works of agriculture ranging from ploughing, showing, and harvesting to the marketing of the produce. There is difference of opinion amongst scholar regarding the mechanisation of agriculture. In fact small and scatter land holding, cheap and abundant human labour and poverty amongst farmers go against total mechanisation of Indian agriculture but the possibility of limited mechanisation is not ruled out. In many cases where the use of animal and human power has become costlier, mechanization is proving to be boon for agriculture. Even small farmers prefer to use these machineries to save the time and money. 


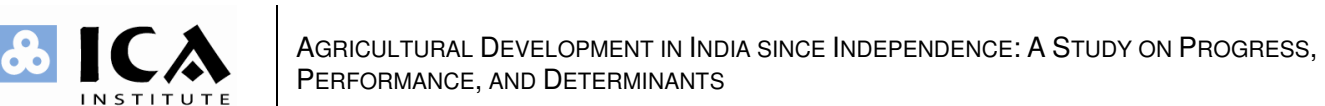

Table 13: Production, Import, and Consumption of Fertiliser

(In thousand tonnes)

\begin{tabular}{lcccccc}
\hline & $1950 / 51$ & $1960 / 61$ & $1970 / 71$ & $1980 / 81$ & $1990 / 91$ & $2000 / 01$ \\
\hline A. Nitrogen & & & & & & \\
\hline Production & 09 & 98 & 830 & 2164 & 6993 & 10961 \\
\hline Imports & & 399 & 477 & 1510 & 414 & 154 \\
\hline Consumption & & 210 & 1487 & 3678 & 7997 & 10920 \\
\hline B. Phosphatic & & & & & & \\
\hline Production & 09 & 52 & 229 & 841 & 2052 & 3743 \\
\hline Imports & & & 32 & 452 & 1016 & 396 \\
\hline Consumption & & 53 & 462 & 1214 & 3221 & 4215 \\
\hline C. Postassic & & & & & & \\
\hline Production & & & & & & \\
\hline Imports & & 20 & 120 & 797 & 1328 & 1541 \\
\hline$\quad$ Consumption & & 29 & 228 & 624 & 1328 & 1567 \\
\hline D. All fertilisers & & & & & & \\
\hline Production & 39 & 150 & 1059 & 3005 & 9045 & 14704 \\
\hline Imports & 52 & 419 & 629 & 2759 & 2758 & 2090 \\
\hline Consumption & 70 & 292 & 2177 & 5516 & 12546 & 16702 \\
\hline
\end{tabular}

Source: Indian Economic Survey, 2002-03

Table 14: Fertiliser Consumption per Hectare of Agricultural Land in Selected Countries in 2004-05

\begin{tabular}{lrrrr} 
& & & \multicolumn{2}{c}{ (In KG per Hectare) } \\
\hline Countries & $\mathrm{N}$ & $\mathrm{P}$ & $\mathrm{K}$ & Total \\
\hline Egypt & 476.2 & 67.6 & 11.3 & 555.1 \\
\hline Bangladesh & 128.6 & 37.4 & 18.5 & 184.5 \\
\hline India & 65.0 & 25.7 & 11.4 & 102.1 \\
\hline Japan & 116.0 & 137.4 & 109.5 & 362.9 \\
\hline Korea Rep. & 208.3 & 82.9 & 103.5 & 394.7 \\
\hline Pakistan & 92.6 & 26.6 & $\mathrm{NA}$ & 119.2 \\
\hline Sri Lanka & 69.3 & 14.8 & 25.8 & 109.9 \\
\hline Belarus & 47.7 & 12.1 & 55.6 & 115.4 \\
\hline Denmark & 80.3 & 13.0 & 36.7 & 130.0 \\
\hline France & 80.1 & 26.0 & 33.1 & 139.2 \\
\hline Germany & 104.5 & 21.1 & 28.1 & 153.7 \\
\hline Netherlands & 142.4 & 29.6 & 77.4 & 249.4 \\
\hline Norway & 101.4 & 12.4 & 44.7 & 158.5 \\
\hline Poland & 53.4 & 24.8 & 37.9 & 116.1 \\
\hline United Kingdom & 66.8 & 16.0 & 22.3 & 105.1 \\
\hline \multicolumn{1}{c}{ Source: Agricultural Statistics at a Glance $(2008)$} & &
\end{tabular}


Studies show that sufficient progress has been made in respect of farm mechanisation in India. For example, the number of tractors which was less than 10000 in 1950-51 increased to 1 lakh in 1970-71 and 14.5 lakhs in 1990-91. Similarly, the number of diesel pump sets increased from 80,000 in 1950-51 to 48.5 lakhs in 1990-91 and electric irrigation pump sets from 26,000 in 1950-51 to 91 lakhs in 1990-91. But most of the mechanisation has largely been confirmed to the rich farmers belonging to the developed areas of the country.

\section{Sources of Growth in Indian Agriculture}

Any change in the output of a crop in physical term ${ }^{4}$ depends fundamentally on the changes in the area under the crop and its average yield. To measure the effect of area, productivity and their interaction in increasing the crop output, differential equation given by Sharma (1977) was used:

$\Delta \mathrm{P}=\mathrm{A} \Delta \mathrm{Y}+\mathrm{Y} \Delta \mathrm{A}+\Delta \mathrm{A} \Delta \mathrm{Y}$

The first term on the right hand side is considered as yield effect, second term as the area effect and the third as the interaction effect. Thus, total change in output can be decomposed into three effects; yield effect, area effect, and the interaction effect due to change in yield and area.

During 1950/51-1965/66, area and yield both almost equally contributed in growth of rice, wheat, and coarse cereals. But for non-food crops, expansion area was dominant source of output growth (see Table 15).

During 1965/66-1980/81, increase in yield was comparatively more contributed in output growth of all major crops except Wheat and Jute and Mesta. For Wheat, 40.49 percent of output growth was contributed by expansion in area and 34.46 percent was contributed by increase in yield. Remaining part (25 percent) of output growth of Wheat was contributed by interaction of area and yield (see Table 16).

During 1981/82-1990/91, an increase in yield was more contributed in output growth of all major crops except oilseeds and sugarcane (see Table 17).

${ }^{4}$ Agricultural output may be measured either in nominal or physical terms. The output measured in physical term obviates the need for incorporation of price effect in decomposition of the changes in output. 
Table 15: Sources of Agricultural Growth in Period: (1950/511965/66)

\begin{tabular}{lllll}
\hline Crop & $\begin{array}{l}\text { Change in } \\
\text { Output }\end{array}$ & Area Effect & Yield Effect & $\begin{array}{l}\text { Interaction } \\
\text { Effect }\end{array}$ \\
\hline Rice & 10010 & $3112.7(31.1)$ & $5991.1(59.85)$ & $906.16(9.05)$ \\
\hline Wheat & 3940 & $1868.43(47.42)$ & $1606.83(40.78)$ & $464.74(11.79)$ \\
\hline $\begin{array}{l}\text { Coarse } \\
\text { Cereals }\end{array}$ & 6040 & $2723.24(45.1)$ & $2817.82(46.65)$ & $498.93(8.26)$ \\
\hline Pulses & 1530 & $1600.83(104.63)$ & $-57.27(-3.74)$ & $-10.89(-0.7)$ \\
\hline Oil seeds & 1240 & $2174.12(175.33)$ & $-665.26(-53.65)$ & $-280.24(-22.6)$ \\
\hline Cotton & 307.7 & $183.04(59.49)$ & $94.08(30.57)$ & $33.28(10.82)$ \\
\hline Jute \& Mesta & 444.6 & $563.22(126.68)$ & $-60.99(-13.72)$ & $-57.78(-13)$ \\
\hline Sugarcane & 66940 & $37767(56.42)$ & $17604(26.30)$ & $11633(17.38)$ \\
\hline Tobaco & 30 & $14.62(48.73)$ & $16.92(56.4)$ & $0.94(3.13)$ \\
\hline Potato & 2420 & $1660.1(68.60)$ & $383.04(15.83)$ & $383.04(15.83)$ \\
\hline
\end{tabular}

Table 16: Sources of Agricultural Growth in Period: (1966/67 1980/81)

\begin{tabular}{lllll}
\hline Crop & $\begin{array}{l}\text { Change in } \\
\text { Output }\end{array}$ & Area Effect & Yield Effect & $\begin{array}{l}\text { Interaction } \\
\text { Effect }\end{array}$ \\
\hline Rice & 11890 & $3598.7(30.3)$ & $7431.4(62.5)$ & $879.12(7.4)$ \\
\hline Wheat & 20440 & $8276.38(40.49)$ & $7044.7(34.46)$ & $5118.93(25.04)$ \\
\hline $\begin{array}{l}\text { Coarse } \\
\text { Cereals }\end{array}$ & 4970 & $-1765.48(-35.52)$ & $7269.1(146.26)$ & $-533.61(10.74)$ \\
\hline Pulses & 2280 & $128.18(5.62)$ & $2123.52(93.14)$ & $32.64(1.43)$ \\
\hline Oil seeds & 2940 & $1112.8(37.85)$ & $1560(53.06)$ & $270.4(9.2)$ \\
\hline Cotton & 295.8 & $-2.28(-0.77)$ & $297.92(100.72)$ & $-0.76(-0.26)$ \\
\hline Jute \& Mesta & 284.4 & $190.44(66.96)$ & $80.64(28.35)$ & $12.96(4.56)$ \\
\hline Sugarcane & 61420 & $14924(24.3)$ & $40268(65.56)$ & $6478(10.55)$ \\
\hline Tobaco & 130 & $25.02(19.25)$ & $97.02(74.63)$ & $6.93(5.33)$ \\
\hline Potato & 6150 & $1934.4(31.45)$ & $2734.5(44.46)$ & $1512.7(24.60)$ \\
\hline
\end{tabular}

Table 17: Sources of Agricultural Growth in Period: (1981/821990/91)

\begin{tabular}{lllll}
\hline Crop & $\begin{array}{l}\text { Change in } \\
\text { Output }\end{array}$ & Area Effect & Yield Effect & $\begin{array}{l}\text { Interaction } \\
\text { Effect }\end{array}$ \\
\hline Rice & 20660 & $3392.8(16.4)$ & $16240(78.6)$ & $1027.4 \quad(5)$ \\
\hline Wheat & 17690 & $3432.73(19.40)$ & $13070.14(73.9)$ & $1198.4(6.8)$ \\
\hline $\begin{array}{l}\text { Coarse } \\
\text { Cereals }\end{array}$ & 1610 & $-4493.29(-279.1)$ & $7103.175(441.12)$ & $-1025.74(63.7)$ \\
\hline Pulses & 2750 & $396.06(14.40)$ & $2264.8(82.36)$ & $77.9(2.83)$ \\
\hline Oil seeds & 6530 & $3348.36(51.28)$ & $2496.12(38.22)$ & $691.68(10.59)$ \\
\hline Cotton & 333.2 & $-102.9(-30.89)$ & $475.54(142.72)$ & $-36.58(-10.98)$ \\
\hline Jute \& Mesta & 154.8 & $-170.4(-110.1)$ & $371.45(239.95)$ & $-41.99(-27.13)$ \\
\hline Sugarcane & 54690 & $29180(53.35)$ & $22445(41.04)$ & $3518(6.43)$ \\
\hline Tobaco & 40 & $-35.16(-87.9)$ & $79.64(199.1)$ & $-5.43(-13.58)$ \\
\hline Potato & 5300 & $2339.28(44.14)$ & $2476.1(46.72)$ & $586.44(11.06)$ \\
\hline
\end{tabular}


During 1991/92-2005/06, again yield's contribution in output growth of all major crops except Wheat, Sugarcane, and Potato was greater than expansion in area. It is a matter of great concern as to why the productivity of wheat and sugarcane remains stagnant (see Table 18).

Table 18: Sources of Agricultural Growth in Period: (1991/922006/07)

\begin{tabular}{lllll}
\hline Crop & $\begin{array}{l}\text { Change in } \\
\text { Output }\end{array}$ & Area Effect & Yield Effect & Interaction Effect \\
\hline Rice & 16370 & $1838.5(11.23)$ & $14203(86.8)$ & $349.65(2.01)$ \\
\hline Wheat & 18010 & $11755(65.27)$ & $5181.42(28.77)$ & $1093.76(6.07)$ \\
\hline Coarse & 6930 & -3872.84 & $12710.36(183.41)$ & $-1894(-27.33)$ \\
Cereals & & $55.88)$ & & \\
\hline Pulses & 2090 & $650.26(31.11)$ & $1374.94(65.79)$ & $74.42(3.56)$ \\
\hline Oil seeds & 4660 & $71.9(1.54)$ & $4556.64(97.78)$ & $17.6(0.38)$ \\
\hline Cotton & 1926.1 & $317.52(16.48)$ & $1348.2(70)$ & $258.72(13.43)$ \\
\hline Jute \& Mesta & 189 & $-265.9(-140.7)$ & $546.12(288.95)$ & $-78.72(-41.65)$ \\
\hline Sugarcane & 68940 & $65408(94.88)$ & $2933.8(4.25)$ & $756.36(1.1)$ \\
\hline Tobaco & -30 & $-2.34(7.8)$ & $48.256(-160.9)$ & $-6.73(22.44)$ \\
\hline Potato & 7520 & $5884.48(78.25)$ & $1188.8(15.81)$ & $427.04(5.68)$ \\
\hline
\end{tabular}

\section{Instability in Indian Agriculture}

Instability is one of the important decision parameters in development dynamics and more so in the context of agricultural production. An analysis of fluctuations in crop output, apart from growth, is of importance for understanding the nature of food security and income stability. Wide fluctuations in crop output not only affect prices and bring about sharp fluctuation in them but also results in wide variations in disposable income of the farmers. The magnitude of fluctuations depends on the nature of crop production technology, its sensitivity to weather, economic environment, availability of material inputs and many other factors. High growth in production accompanied by low level of instability for any crop is desired for sustainable development of agriculture.

In this section we examined extent of production, area, and yield instability for major crops. The instability in area, production and yield of major crops is measured in relative terms by the Cuddy-Della Valle index which is used in recent years by a number of researchers as a measure of variability in time series data. The simple coefficient of variation overestimates the level of instability in time-series data characterized by long term trends whereas the Cuddy-Della Valle index corrects the coefficient of variation. 
The instability index IX, is given by the expression:

$I X=C V \times \sqrt{1-\bar{R}^{2}}$

Where,

$\mathrm{CV}=$ Coefficient of variation (in percent)

$\bar{R}^{2}=$ Coefficient of determination from a time-trend regression adjusted by the number of degrees of freedom

The $\mathrm{CV}$ is calculated by using this formula: $C V=\frac{\sigma}{\bar{R}}$ where, $\sigma={ }_{\text {standard deviation }^{5} \text { and }}$ $X=$ mean $^{6}$.

It may be mentioned here that some researchers have estimated the $\mathrm{CV}$ around trend as the standard error of regression divided by mean. After estimating in both ways from the same set of data, Sindh and Byerlee (1990) found that the results are almost identical whichever method is used. Since both methods provide the same results, we decided to estimate the instability index using the Cuddy-Della Valle index. Thus, instability index are calculated for the pre-green revolution, post-green revolution period, and post-reform period. These results are shown in Tables 20, 21, and 22. For wheat, rice, pulses, oilseeds, cotton, jute, and potato, these measures show decrease in production instability during post-reform period. This indicates that post-reform period helps in reducing production instability for these crops. Yet, despite this decrease in production instability, corse cereals, sugarcane, and tobacco realized an increment in production instability during post-reform period. Area instability for wheat, jute, sugarcane, and potato decreased by 49.43 percent, 41.36 percent, 5.5 percent, 13 percent, respectively and for rice, corse cereals, pulses, oilseeds, cotton, and tobacco increased by 22 percent, 33 percent, 11 percent, 35 percent, 65 percent, and 60 percent, respectively in post-reform period. Further, the results indicates that the yield instability for rice, wheat, corse cereals, pulses, jute and sugarcane declined by 36 percent, 37 percent, 6 percent, 32 percent, 64 percent, and 0.4 percent, respectively during postreform period. But Yield instability for oilseeds, cotton, potato, and tobacco increased by 3 percent, 93 percent, 11 percent, 19 percent, respectively. Production instability was the highest for tobacco (15.03), oilseeds (14.93), jute (14.65), cotton (10.86), and coarse cereals (10.42). Yield instability was the largest for cotton (20.54), and oilseeds (10.38).

\footnotetext{
${ }^{5}$ The Standard deviation is equal to $\sigma=\sqrt{\frac{\sum\left(x-\Omega^{2}\right.}{n}}$

${ }^{6}$ The arithmetic mean is equal to $\bar{x}=\frac{\sum_{l=1}^{n} x_{2}}{\mathrm{n}}$
} 
Table 20: Instability in Production

\begin{tabular}{|c|c|c|c|c|c|c|}
\hline Crop & Pre-gre & $\mathrm{n}$ revolution & Post-gre & en revolution & Post-ref & rm \\
\hline & CV & $\begin{array}{l}\text { Instability } \\
\text { Index }\end{array}$ & CV & Instability Index & CV & Instability Index \\
\hline Wheat & 19.315 & 9.71 & 36.429 & 10.46 & 8.845 & 6.21 \\
\hline Rice & 18.881 & 8.95 & 23.310 & 9.03 & 8.017 & 6.77 \\
\hline Corse & & & & & & \\
\hline Cereals & 13.267 & 9.20 & 10.562 & 9.17 & 10.544 & 10.42 \\
\hline Pulses & 13.428 & 11.59 & 12.777 & 10.94 & 8.835 & 9.15 \\
\hline Oil Seeds & 16.003 & 8.83 & 30.317 & 14.89 & 14.918 & 14.93 \\
\hline Cotton & 20.008 & 11.86 & 21.063 & 11.83 & 20.730 & 10.86 \\
\hline Jute & 25.922 & 16.58 & 23.160 & 19.86 & 26.836 & 14.65 \\
\hline Sugar cane & 32.166 & 12.74 & 23.873 & 9.51 & 9.600 & 9.64 \\
\hline Potato & 30.655 & 13.56 & 44.046 & 9.97 & 16.205 & 9.64 \\
\hline Tobacco & 14.935 & 9.90 & 16.504 & 11.43 & 15.107 & 15.03 \\
\hline
\end{tabular}

Table 21: Instability in Area

\begin{tabular}{|c|c|c|c|c|c|c|}
\hline \multirow[t]{2}{*}{ Crop } & \multicolumn{2}{|c|}{ Pre-green revolution } & \multicolumn{2}{|c|}{ Post-green revolution } & \multicolumn{2}{|c|}{ Post-reform } \\
\hline & CV & $\begin{array}{l}\text { Instability } \\
\text { Index }\end{array}$ & CV & Instability Index & CV & Instability Index \\
\hline Wheat & 12.299 & 6.86 & 15.455 & 7.00 & 4.338 & 3.54 \\
\hline Rice & 6.692 & 1.69 & 5.053 & 2.38 & 2.836 & 2.91 \\
\hline Corse & & & & & & \\
\hline Cereals & 4.954 & 3.91 & 7.480 & 2.78 & 6.382 & 3.70 \\
\hline Pulses & 8.459 & 5.40 & 4.326 & 3.90 & 4.235 & 4.33 \\
\hline Oil Seeds & 12.232 & 3.29 & 13.277 & 5.53 & 7.424 & 7.52 \\
\hline Cotton & 9.666 & 6.40 & 5.165 & 4.92 & 8.315 & 8.14 \\
\hline Jute & 22.878 & 13.78 & 13.426 & 13.71 & 7.764 & 8.04 \\
\hline Sugar cane & 18.313 & 9.62 & 13.565 & 7.46 & 7.781 & 7.05 \\
\hline Potato & 22.312 & 3.26 & 23.526 & 5.70 & 10.268 & 4.95 \\
\hline Tobacco & 9.609 & 7.47 & 9.277 & 8.90 & 15.006 & 14.29 \\
\hline
\end{tabular}


Table 22: Instability in Yield

\begin{tabular}{lrrrrrrr}
\hline Crop & Pre-green revolution & \multicolumn{2}{l}{ Post-green revolution } & \multicolumn{2}{l}{ Post-reform } \\
& CV & $\begin{array}{l}\text { Instability } \\
\text { Index }\end{array}$ & & CV & Instability Index & CV & Instability Index \\
& 10.144 & 7.71 & 24.136 & 6.17 & 5.450 & 3.92 \\
\hline Wheat & 13.220 & 8.38 & 18.587 & 7.49 & 6.243 & 4.74 \\
\hline Rice & & & & & & \\
\hline Corse & 8.707 & 6.43 & 15.135 & 8.13 & 11.060 & 7.64 \\
Cereals & 7.896 & 8.15 & 10.349 & 9.29 & 6.222 & 6.33 \\
\hline Pulses & 8.394 & 8.48 & 16.585 & 10.10 & 11.538 & 10.38 \\
\hline Oil Seeds & 13.166 & 9.37 & 22.018 & 10.64 & 20.579 & 20.54 \\
\hline Cotton & 5.934 & 6.04 & 15.824 & 8.10 & 8.360 & 2.94 \\
\hline Jute & 15.363 & 7.02 & 12.367 & 5.02 & 4.997 & 5.00 \\
\hline Sugar cane & 10.849 & 10.56 & 23.076 & 7.12 & 8.932 & 7.89 \\
\hline Potato & 7.904 & 5.90 & 16.135 & 5.22 & 6.205 & 6.20 \\
\hline Tobacco & 7.96
\end{tabular}

Overall analysis indicates that production and yield instability for almost crops declined in post-reform period. But further it also indicates that area instability increased in the same period. Therefore, it can be concludes that reduction in production instability is mainly due to reduction in instability of yield and present instability in production is mainly because of increasing instability in area.

\section{Determinates of Agricultural Production}

This section aims at analyzing the impact of production variables (inputs) on agricultural output growth. For this purpose we used Cobb-Douglus Production Function specified as:

$\log _{\mathrm{e}}(\mathrm{GVAO})=\beta_{0}+\beta_{1} \log _{\mathrm{e}}(\mathrm{L})+\beta_{2} \log _{\mathrm{e}}(\mathrm{M})+\beta_{3} \log _{\mathrm{e}}(\mathrm{K})+\varepsilon_{\mathrm{t}}$

where $G V A O$ is gross value of agricultural output; $L$ is agricultural land force; $K$ is capital input; $M$ is agricultural labour; Coefficients $\beta_{i}(\mathrm{i}=1,2,3)$ are the elasticities of the respective variables with respect to agricultural production, with the assumption that $\beta_{i}>0$.

The data used in the estimation of production function were country level agricultural output and inputs for estimating the Cobb-Douglas production function of Indian agriculture from 1950/51 to 2005/06. Most previous studies on Indian agriculture used gross value of agricultural output (GVAO) as the total value of agricultural production. GVAO is defined as the sum of the total value of production from farming, forestry, livestock, and fishery. The sum of output of all products of farming, livestock, forestry, and fishery equals to GVAO and is expressed at constant (1999/2000) prices. The data on 
GVAO were taken from the National Account Statistics (Back series 1950 to 2000, and 2008) published from Central Statistical Organization, Government of India.

Labour, land, and capital are considered the three main inputs in agricultural production. Labour input is measured as workforce involved in agriculture. The data of workforce in agriculture is given in Agricultural Statistics at a Glance (2008) published from Directorate of Economics and Statistics, Ministry of Agriculture, Government of India only for census year. This series was interpolated for making time series data. Land input refers to the net cultivated area and is measured by net sown area. The data were taken from Agricultural Statistics at a Glance (2008). Capital stock of a country is broadly referred to as that part of national wealth which is reproducible; it consists of all resources which contribute to the production of goods and services. Capital is measured in terms of net fixed capital stock in agriculture and data related to net fixed capital stock are taken from Nation Account Statistics. This capital stock measure includes agricultural machinery, farm equipment and tools, transport equipment in farm business, land improvements, investments in private and public irrigation, and farm houses.

Results for the Cobb-Douglas estimates are reported in Tables 23.1, 23.2, \& 23.3. The estimated agricultural production function for Indian agriculture based on data during $1950 / 51$ to $2005 / 06$ can be expressed in the following mathematical form:

$\log _{\mathrm{e}}(\mathrm{GVOA})=-0.44+0.32 \log _{\mathrm{e}}(\mathrm{L})+0.88 \log _{\mathrm{e}}(\mathrm{M})+0.36 \log _{\mathrm{e}}(\mathrm{K})$
$(3.12)$

From the above equation, we can see that in Indian agriculture during 1950/51 to 2005/06, the output elasticities of land, labour, and capital were $0.32,0.88$, and 0.36 respectively. If $\alpha=0.32$, and the land input increases to about 1 percent, then the gross value of agricultural output increases 0.32 percent. Similarly, $\beta=0.88$, and $\gamma=0.36$ can be interpreted in the same way. The sum $(\alpha, \gamma$, and $\beta$ ) gives information about the returns to scale, that is, response of output to a proportionate change in the input, in our case adding the three output elasticities we obtain 1.56 , which gives the value of the returns to scale parameter. As we can see the sum is greater than 1, thus there are increasing returns to scale. As is evident, over the period of the study, the Indian agriculture is characterized by increasing returns to scale doubling the inputs will more than double the output. 
Table 23.1: Model (without dummy variables) Summary

\begin{tabular}{ccc}
\hline Model & Adjusted $\mathrm{R}^{2}$ & $\begin{array}{c}\text { Std. error of the } \\
\text { estimate }\end{array}$ \\
\hline 1 & 0.986 & 0.05048 \\
\hline
\end{tabular}

Table 23.2: Analysis of Variance (ANOVA)

\begin{tabular}{cccccc}
\hline Model & $\begin{array}{c}\text { Sum of } \\
\text { Squares }\end{array}$ & Df & Mean Square & $F$ & Sig. \\
\hline 1 Regression & 10.384 & 3 & 3.461 & 1358.32 & 0.000 \\
\hline Residual & 0.130 & 51 & 0.002 & & \\
\hline Total & 10.514 & 54 & & & \\
\hline
\end{tabular}

Table 23.3: Coefficients

\begin{tabular}{llllll}
\hline Variables & Coeff. & Std. Err. & t- Value & Adj- R $^{2}$ & DW- Stat. \\
\hline Cons. & -0.44 & 3.123 & -0.14 & & \\
\hline Nsa & 0.32 & 0.318 & 1.02 & .986 & 1.120 \\
\hline Labr & $0.88^{*}$ & 0.059 & 14.81 & & \\
\hline Cptl & $0.36^{*}$ & 0.063 & 5.75 & & \\
\hline
\end{tabular}

${ }^{*}$ Significant at 1 percent level

From a purely statistical viewpoint, the estimated regression line fits the data quite well. The $\mathrm{R}^{2}$ value of 0.99 means that 99 percent of the variation in the (logarithmic of) gross value of agricultural output is explained by the (logarithmic of) land, labour, and capital. For adjusted $\mathrm{R}^{2}$ the relation is 99 percent. This shows the statistical dependence of the (logarithmic of) gross value of agricultural output on the (logarithmic of) labour, land and capital, and $\gamma$ and $\beta$ are statistically significant at the 1 percent level and $\alpha$ is not significant. The dw-statistic is equal to 1.121. From the Durbin-Watson tables, we found that for 55 observation and three explanatory variables, $\mathrm{d}_{\mathrm{L}}=1.414$ and $\mathrm{d}_{\mathrm{U}}=1.724$ at the 5 percent level. Since the computed dw-statistics lies below $\mathrm{d}_{\mathrm{L}}$, cannot reject the hypothesis that there is positive autocorrelation.

Despite the problem of autocorrelation, intercept and output elastities estimated by equation 2 are constant over period of time. But in real it is not true, i.e., intercept and output elasitcties are variable over period of time. This is because of structural changes that occurred in economy during a period of time. The structural changes also occurred in Indian Agriculture. Pulapre, Balakrishnan, and Parameswaran (2007) identified agricultural growth shows trend break in 1964/65 when growth accelerates. It means that there are two growth regimes in Indian Agriculture since 1950. One is from 1950/51 to 1964/65 and second is beyond 1964/65. Expansion of area was the main source of growth in the first regime of agricultural growth after that the contribution of increased land area under agricultural production has declined over time and increase in productivity became the main source of 
growth in agricultural production in second regime of agricultural growth. This estimation have confirmed that intercept and output elasticites are not constant over the period of time. To solve this problem, we have used dummy variables, i.e., 0 for observations in 1950/511964/65 and 1 for observations in 1965/66-2005/06, in equation 2.

First, we hypothesized that only level of agricultural output (intercept) has changed between these two regimes of agricultural growth. So, to capture this difference, we have incorporated intercept dummy in equation 3:

$\log _{\mathrm{e}}(\mathrm{GVAO})=\beta_{0}+\beta_{1} \log _{\mathrm{e}}(\mathrm{L})+\beta_{2} \log _{\mathrm{e}}(\mathrm{M})+\beta_{3} \log _{\mathrm{e}}(\mathrm{K})+\beta_{4} \mathrm{D}_{\mathrm{t}}+\varepsilon_{\mathrm{t}}$

Next we hypothesized that both level of agricultural output (intercept) and output elasticities have changed between these two regimes of agricultural growth. To capture these differences, we have incorporated both intercept dummy and slop dummy in equation 3. The equation 3 becomes:

$\log _{\mathrm{e}}(\mathrm{GVAO})=\beta_{0}+\beta_{1} \log _{\mathrm{e}}(\mathrm{L})+\beta_{2} \log _{\mathrm{e}}(\mathrm{M})+\beta_{3} \log _{\mathrm{e}}(\mathrm{K})+\beta_{4} \mathrm{D}_{\mathrm{t}}+\beta_{5}\left[\mathrm{D}_{\mathrm{t}} \log _{\mathrm{e}}(\mathrm{L})\right]$

$+\beta_{6}\left[\mathrm{D}_{\mathrm{t}} \log _{\mathrm{e}}(\mathrm{M})\right]+\beta_{7}\left[\mathrm{D}_{\mathrm{t}} \log _{\mathrm{e}}(\mathrm{K})\right]+\varepsilon_{\mathrm{t}}$

Results for the Cobb-Douglas Production function with only intercept dummy (equation 4) estimates are reported in Tables 24.1, 24.2, \& 24.3. The estimated agricultural production function with only intercept dummy for Indian agriculture based on data from 1950/51 through 2005/06 can be expressed in the following mathematical form:

$\log _{\mathrm{e}}(\mathrm{GVAO})=-0.48+0.38 \log _{\mathrm{e}}(\mathrm{L})+0.98 \log _{\mathrm{e}}(\mathrm{M})+0.27 \log _{\mathrm{e}}(\mathrm{K})+0.06 \mathrm{D}_{\mathrm{t}}$
(3.079)
(0.316)
$(0.085)$
$(0.086)$
$(0.04)$

From the above equation, we can see that in Indian agriculture during the period 1950-51 to 2005-06, the output elasticities of land, labour, and capital were $0.38,0.98$, and 0.27 , respectively. The coefficient of intercept dummy is 0.06 . This indicates that intercept increased by 0.06 from period first to second. It means that intercept was -0.48 in period $1950 / 65$ and becomes $-0.42(-0.48+0.06)$ in period 1965/2006.

From a purely statistical viewpoint, the estimated regression line fits the data quite well in comparison to equation 2. In this equation also $\gamma$ and $\beta$ are statistically significant at the 1 percent level and $\alpha$ is not significant. The coefficient of intercept dummy is also not statistically significant. This reveals that there is no difference in intercept or level of agricultural output between two periods; 1950-65 and 1965-2006. The dw-statistic is equal to 1.202 . In this case also the computed $\mathrm{dw}$-statistics lies below $\mathrm{d}_{\mathrm{L}}$; cannot reject the hypothesis that there is positive autocorrelation. 
Table 24.1: Model (with intercept dummy) Summary

\begin{tabular}{ccc}
\hline Model & ${\text { Adjusted } \mathrm{R}^{2}}$ & $\begin{array}{c}\text { Std. error of the } \\
\text { estimate }\end{array}$ \\
\hline Predictors (Constant), LNL, LNM, LNK, Dependent Variable LNGVAO & 0.987 & 0.04976 \\
\hline
\end{tabular}

Table 24.2: Analysis of Variance (ANOVA)

\begin{tabular}{cccccc}
\hline Model & $\begin{array}{c}\text { Sum of } \\
\text { Squares }\end{array}$ & Df & Mean Square & F & Sig. \\
\hline 2 Regression & 10.390 & 4 & 2.598 & 1049.00 & 0.000 \\
\hline Residual & 0.124 & 50 & .002 & & \\
\hline Total & 10.514 & 54 & & & \\
\hline Predictors (Constant), LNL, LNM, LNK, Dependent Variable LNGVAO
\end{tabular}

Table 24.3: Coefficients

\begin{tabular}{llllll}
\hline Variables & Coeff. & Std. Err. & t- Value & Adj- ${ }^{2}$ & DW- Stat. \\
\hline Cons. & -0.48 & 3.079 & -0.16 & & \\
\hline dummy & 0.063 & 0.039 & 1.58 & & \\
\hline Nsa & 0.38 & 0.316 & 1.21 & .987 & 1.202 \\
\hline Labr & $0.98^{*}$ & 0.085 & 11.44 & & \\
\hline Cptl & $0.27^{*}$ & 0.086 & 3.13 & & \\
\hline
\end{tabular}

${ }^{*}$ Significant at 5 percent level

Results for the Cobb-Douglas Production function with both intercept and slop dummy (equation 5) estimates are reported in Tables 25.1, 25.2, \& 25.3. The estimated agricultural production function with both intercept and slop dummy for Indian agriculture based on data during the period 1950-51 to 2005-06, can be expressed in the following mathematical form:

$\log _{\mathrm{e}}(\mathrm{GVAO})=-14.10+2.34 \log _{\mathrm{e}}(\mathrm{L})-0.26 \log _{\mathrm{e}}(\mathrm{M})-0.04 \log _{\mathrm{e}}(\mathrm{K})+4.24 \mathrm{D}_{\mathrm{t}}-1.09\left[\mathrm{D}_{\mathrm{t}}\right.$ $\left.\log _{\mathrm{e}}(\mathrm{L})\right]+1.13\left[\mathrm{D}_{\mathrm{t}} \log _{\mathrm{e}}(\mathrm{M})\right]+0.27\left[\mathrm{D}_{\mathrm{t}} \log _{\mathrm{e}}(\mathrm{K})\right]+\varepsilon_{\mathrm{t}}$

From the above equation, we can be seen that in Indian agriculture during 1950/5-1964/65, the output elasticities of land, labour, and capital were $2.34,-0.26$, and - 0.04, respectively, and during 1965/66-2005/06, the output elasticities of land, labour, and capital were 1.25, 0.87 , and 0.23 . The sum of output elasticities (returns to scale) was 2.04 during 1950/51$1964 / 65$ and increased to 2.35 during 1965/66-2005/06. 
Table 25.1: Model (with intercept dummy) Summary

\begin{tabular}{ccc}
\hline Model & Adjusted $\mathrm{R}^{2}$ & $\begin{array}{c}\text { Std. error of the } \\
\text { estimate }\end{array}$ \\
\hline 3 & 0.995 & 0.02945 \\
\hline
\end{tabular}

Table 25.2: Analysis of Variance (ANOVA)

\begin{tabular}{cccccc}
\hline Model & $\begin{array}{c}\text { Sum of } \\
\text { Squares }\end{array}$ & Df & Mean Square & $F$ & Sig. \\
\hline 2 Regression & 10.474 & 7 & 1.496 & 1725.34 & 0.000 \\
\hline Residual & 0.041 & 47 & .001 & & \\
\hline Total & 10.514 & 54 & & & \\
\hline
\end{tabular}

Table 25.3: Coefficients

\begin{tabular}{llllll}
\hline Variables & Coeff. & Std. Err. & t- Value & Adj- $R^{2}$ & DW- Stat. \\
\hline Cons. & -14.10 & 5.411 & -2.61 & & \\
\hline Dummy & 4.20 & 5.881 & 0.71 & & \\
Nsa & $2.34^{*}$ & 0.623 & 3.75 & .987 & 1.202 \\
Dnsa & -1.09 & 0.664 & -1.64 & & \\
Labr & -0.26 & 0.181 & -1.42 & & \\
Dlabr & $1.13^{*}$ & 0.196 & 5.80 & & \\
Cptl & -0.04 & 0.128 & -0.31 & & \\
Dcptl & $0.27^{* *}$ & 0.143 & 1.88 & & \\
\hline
\end{tabular}

* Significant at 5 percent level

From a purely statistical viewpoint, the estimated regression line fits the data quite well in comparison to other two regression lines (3 and 4). Only the coefficient of land is statistically significant at 1 percent level and the coefficient of labour and capital are not statistically significant during the period 1950-51 to 1964-65. While in the period 1965-66 to 2005-06 the coefficient of labour and capital are statistically significant at 1 percent and 5 percent level, respectively and the coefficient of land is not statistically significant. This shows that land significantly affected the agricultural output growth during 1950/511964/65 and after that land became less significant and now labour and capital are significantly affecting the agricultural output growth. The dw-statistic is equal to 1.718. From the Durbin-Watson tables, for 55 observation and seven explanatory variables, $\mathrm{d}_{\mathrm{L}}=$ 1.253 and $\mathrm{d}_{\mathrm{U}}=1.909$ at the 5 percent level. Since the computed dw-statistics lies between $\mathrm{d}_{\mathrm{L}}$ and $\mathrm{d}_{\mathrm{U}}$, autocorrelation is inconclusive. 


\section{Concluding Remarks}

This paper evaluates performance and progress of Indian Agriculture since Independence. In addition, this paper also analyzes sources of agricultural growth and determinants of agricultural production. We use the decomposition test to analyze sources of agricultural growth and the production function approach to analyze determinants of agricultural production over the period 1950/51 through 2005/06. The study indicates that there is scope to increase both net sown area and gross sown area. The study also highlights that only 39 percent of net sown area is irrigated area. After evaluating the changes in agrarian structure, input use pattern and growth trend of agriculture, this paper point outs some points. These are: agricultural workforce shifted from cultivators to agricultural labours, the number of uneconomic holdings has an increasing trend, area under food crops shifted towards non food crops, and within food crops area under cereals has been shifting towards non cereals, growth trend of aggregate agriculture as well as all sub sector of agriculture except forestry is showing declining trend during post-WTO period. It is also observed in this study that production and yield instability declined for almost crop during post reform period while, area instability increased in the same period. This further indicates that instability in area became major responsible factor for production instability.

The decomposition analysis indicates that rising output per hectare is the predominant source of agricultural growth for most of the crops and crop groups. Disaggregating of reference period in four sub periods shows that expansion of agricultural land was the main source of agricultural growth during the period before 1965/66 after that the contribution of increased land area under agricultural production has declined over time and increase in productivity became the main source of growth in agricultural production.

The estimation of aggregate agricultural production function with both intercept and slope dummy indicates that land significantly affected the agricultural output growth during 1950/51-1964/65 and after that land became less significant and now labour and capital are significantly affecting the agricultural output growth. Thus, the result of the aggregate agricultural production function verifies the results of decomposition analysis. 


\section{References}

Balakrishnan, P. and M. Parameswaran (2007), "Understanding Economic Growth in India: A Prerequisite", Economic and Political Weakly, 42: 2915-2922.

Chand Ramesh (2001), "Emerging Trends and Issues in Public and Private Investments in Indian Agriculture: a State wise Analysis", Indian Journal of Agricultural Economics, 56 (2), 161-184.

Chand Ramesh (2003), "Government Intervation in Foodgrain Markets in the Changing Context", Policy Paper 19, National Centre for Agricultural Economics and Policy Research, New Delhi.

Government of India (1961), Annual Report, Planning Commission of India, New Delhi.

Government of India (2008), Agricultural Statistics at a Glance. Directorate of Economics and Statistics, Ministry of Agriculture, New Delhi.

Government of India (2008), National Account statistics (Back Series). Central Statistical Organization, Ministry of statistics and Programme Implementation, New Delhi.

Government of India (2008), National Account statistics. Central Statistical Organization, Ministry of statistics and Programme Implementation, New Delhi.

Greene, W. H. (2007), Econometrics Analysis. New Delhi: Pearson Education.

Gujrati, D. N. (2004), Basic Econometrics. New Delhi: Tata McGraw - Hill.

Kumar, P. (1998), "Food Demand and Supply Projections for India", Agricultural Economic Policy Series 98-01, Indian Agricultural Research Institute, New Delhi.

Mishra, S. N. and Ramesh Chand (1995), "Private and Public Capital Formation in Indian Agriculture: Comments on Complementarity Hypothesis and Others", Economic and Political Weekly, 30 (24): A-64 A-79.

Murthy, K N (2000), "Changes In Taste and Demand Pattern for Cereals", Agricultural Economic Research Review, Vol. 13(1): 26-53.

Pradhan, R. P. (2007), "Indian Agriculture in the Globalization Era: The Performance and Determinants", Journal of Global Economy, 3(1): 3-12.

Radhakrishna, R. and C. Ravi (1992), "Effects of Growth, Relative Price and Preference of Food and Nutrition", Indian Economic Review, 27(special issue in memory of Sukhamoy Chakravarty): 303-323. 
Rao, C.H. Hanumantha (2000), "Declining Demand for Foodgrains in Rural India: Causes and Implications", Economic and Political Weekly, 22 (January): 201-206.

Rao, V. M. (1996), "Agricultural Development with a Human Face", Economic and Political Weekly, 31(26): A-52 - A-62.

Sharma, K. L. (1977), "Measurement of the effect of area, yield, and prices in the increase of value of crop output in India", Agricultural Situation in India, 32(6).

Subramaniam, A. (2008), India's Turn: Understanding the Economic Transformation. New Delhi: Oxford University Press. 